А. Д. Беденюк

А. Є. Бурак

ORCID 0000-0003-2899-6594

С. Й. Гриценко

ДВНЗ «Тернопільський державний медичний університет

імені І. Я. Горбачевського МОЗ України»

\title{
ОСОБЛИВОСТІ ПІДГОТОВКИ ТА ПРОВЕДЕННЯ СТУДЕНТСЬКОЇ ОЛІМПІАДИ З ХІРУРГІЇ У ТЕРНОПІЛЬСЬКОМУ ДЕРЖАВНОМУ МЕДИЧНОМУ УНІВЕРСИТЕТІ ІМЕНІ І. Я. ГОРБАЧЕВСЬКОГО
}

\begin{abstract}
Анотація. У статті розглянуто особливості проведення олімпіади у медичному ВНЗ, аналіз здобутих результатів та перспективи подальшого розвитку. Показано особливості організації та проведення Всеукраїнської студентської олімпіади в Тернопільському державному медичному університеті імені І. Я. Горбачевського на прикладі кафедри хірургії. Доведено необхідність застосування комплексного підходу у підготовці студентів. Зокрема, особливу увагу викладачам кафедр необхідно звертати не лише на теоретичну підготовку студентів, а насамперед на вміння розв'язувати конкретні клінічні випадки біля ліжка хворого та під час операційних втручань, добру орієнтацію в топографічній анатомії та оперативній хірургії. Одним із пріоритетних завдань перед учасниками відбору до 2 етапу є відмінна теоретична та практична база для виконання навичок із надання екстреної медичної допомоги, оскільки більшість Всеукраїнських олімпіад клінічного спрямування включає в себе вищенаведену ланку невід'ємного багажу знань студента-медика.

Проведення відбору студентів для участі у Всеукраїнській олімпіаді з клінічних дисциплін повинно бути багатогранним, а не лише зводитися до відповідей на теоретичні запитання. Вищенаведена підготовка дозволить краще підготувати студентів для майбутньої олімпіади та виховати фахівця високого рівня кваліфікації.
\end{abstract}

Ключові слова: студентська олімпіада; екстрена медицина; відбір; хірургія.

A. D. Bedenyuk, A. Ye. Burak, S. Y. Grytsenko

I. Horbachevsky Ternopil State Medical University

\section{FEATURES OF TRAINING AND HOLDING STUDENT OLYMPIAD ON SURGERY IN TERNOPIL STATE MEDICAL UNIVERSITY}

\begin{abstract}
The article features the organization and holding of the All-Ukrainian Student Olympiad at the Ternopil National Medical University on the example of the Department of Surgery. The necessity of application of the complex approach in training of students is proved. In particular, the teachers of the departments should pay attention not only to theoretical training of students, but above all to the ability to solve specific clinical cases near the patient's bed and during surgical interventions, good orientation in topographical anatomy and operative surgery. One of the priority tasks for the participants of the selection up to stage 2 is an excellent theoretical and practical basis for the implementation of skills in providing emergency medical care, since most of the All-Ukrainian Olympiads of clinical direction include the above-mentioned link of the essential luggage of knowledge of the medical student.

The selection of students for participation in the olympiad on clinical disciplines should be multifaceted, and not merely be reduced to writing answers to theoretical questions. The above training will better train students for the upcoming olympiad and train a high level specialist.
\end{abstract}

Key words: student olympiad; emergency medicine; selection; surgery.

Вступ. Олімпіада - це змагання студентів у творчому застосуванні здобутих знань, умінь і навичок, а також у професійній підготовці майбутніх спеціалістів. Основними завданнями студентських олімпіад є розвиток обдарованої студентської молоді та сприяння реалізації її творчих здібностей із метою системного вдосконалення навчального процесу, що є важливим показником якості освіт-

() А. Д. Беденюк, А. Є. Бурак, С. Й. Гриценко нього процесу та формування конкурентоздатних майбутніх фахівців [1, 6].

Мета статті - розглянути особливості проведення олімпіади у медичному ВНЗ, аналіз здобутих результатів та перспективи подальшого розвитку.

Теоретична частина. Відповідно до статті 54 Закону України «Про вищу освіту», статті 39 Закону України «Про наукову і науково-технічну діяльність» та $з$ метою виявлення та підтримки обда- 
рованої студентської молоді, створення умов для її творчого зростання, активізації науково-дослідної роботи студентів у вищих навчальних закладах, науково-методичного забезпечення системи вищої освіти наказом Міністерства освіти і науки, молоді та спорту України від 13 грудня 2012 р. № 1410 затверджене Положення про проведення Всеукраїнської студентської олімпіади [3, 4]. На цій основі розпрацьоване положення про проведення Всеукраїнської студентської олімпіади в Тернопільському державному медичному університеті імені І. Я. Горбачевського, яке визначає порядок організації та проведення олімпіади з навчальних дисциплін, напрямів та спеціальностей серед студентів університету [2].

Олімпіада проводиться у два етапи. I етап - на базі кафедр університету із визначених навчальних дисциплін, напрямів та спеціальностей, який проводиться у січні - лютому поточного року. Для прикладу наведемо процес відбору студентів на кафедрі хірургії № 1 з урологією, малоінвазивною хірургією та нейрохірургією імені Л. Я. Ковальчука для участі у II етапі Всеукраїнської олімпіади з хірургії. Згідно з рішенням засідання кафедри, пошук талановитих студентів проводиться викладачами протягом всього навчального року. Особливу увагу викладачі нашої кафедри звертають не лише на теоретичну підготовку студентів, а насамперед на вміння розв’язувати конкретні клінічні випадки біля ліжка хворого та під час операційних втручань, добру орієнтацію в топографічній анатомії та оперативній хірургії [5]. Одним із пріоритетних завдань, котрі викладачі ставлять перед учасниками відбору до II етапу, є відмінна теоретична та практична база для виконання навичок із надання екстреної медичної допомоги, оскільки більшість Всеукраїнських олімпіад клінічного спрямування включає в себе вищенаведену ланку невід'ємного багажу знань студента-медика. Таким чином, викладачі кафедри запропонували взяти участь у I етапі Всеукраїнської олімпіади більш як 20 студентам (більшість 3 яких склали студенти 5 та 6 курсів). Суть проведення даного етапу олімпіади зводиться не лише до теоретичної оцінки знань студентів, але і також вміння встановлювати правильні діагнози та визначати правильну тактику лікування. У звичний білет для студентів включені питання інтерпретації сучасних методів діагностики (KT, ЕРХПГ, МРТ, УЗД тощо). Після проведення перевірки отриманих відповідей визначають не менше 5 кращих студентів, з котрими в подальшому проводили співбесіду. Для забезпечення максимальної об’єктивності відбір учасників II етапу олімпіади здійснюється шляхом проведення додаткового тестового етапу в центрі незалежного тестового оцінювання знань студентів університету з усіх заявлених навчальних предметів, напрямів та спеціальностей.

Загалом у Тернопільському державному медичному університеті імені І. Я. Горбачевського у I етапі беруть участь усі бажаючі студенти незалежно від форм навчання, у тому числі іноземці. Оргкомітет підбиває підсумки I етапу та рекомендує переможців I етапу для участі в II етапі олімпіади. Рекомендацією вважається заповнена оргкомітетом анкета учасника II етапу, яка заповнюється на кожного учасника окремо. Склад оргкомітету, журі та строки проведення I етапу олімпіади в університеті затверджуються наказом ректора. Учасники мають право ознайомитися з оцінкою їх роботи та письмово звернутися до апеляційної комісії з приводу об’ єктивності оцінки виконаних ними завдань.

Анкети переможців I етапу надсилаються базовому вищому навчальному закладу до 1 березня поточного року.

II етап проводиться у квітні - травні у вищих навчальних закладах III-IV рівнів акредитації, які визначаються МОН України для проведення II етапу олімпіади (базові вищі навчальні заклади). Базовий вищий навчальний заклад надсилає листизапрошення з інформацією про умови проведення II етапу олімпіади, тематику олімпіадних завдань 3 відповідної навчальної дисципліни, напряму, спеціальності вищим навчальним закладам, студенти яких можуть брати участь у II етапі олімпіади. Кількісний склад учасників II етапу олімпіади визначає оргкомітет базового вищого навчального закладу у рівній кількості від кожного вищого навчального закладу.

II етап олімпіади складається з турів. Кількість турів (теоретичний, практичний, експериментальний тощо), форми їх проведення (письмові роботи, співбесіди, тестування тощо) на кожному етапі визначають оргкомітети.

Дипломом I ступеня нагороджується учасник, який набрав не менше 80 \%, II ступеня - 70 \%, III ступеня - 60 \% від максимально можливої сумарної кількості балів, що дорівнює 100 \%. При цьому кількість переможців не може перевищувати 10 \% від загальної кількості учасників. У разі перевищення кількості переможців оргкомітет залишає за собою право корегування їх кількості при підбитті остаточних підсумків олімпіади. Учасники, які посіли IV-VI місця, а також за оригінальний, нестандартний розв'язок завдань олімпіади нагоро- 
джуються грамотами оргкомітету базового вищого навчального закладу.

За клопотанням оргкомітету олімпіади ректор базового вищого навчального закладу нагороджує грамотами, грошовими преміями, цінними подарунками активних організаторів олімпіади із коштів вищого навчального закладу.

У 2018-2019 навчальному році Тернопільський державний медичний університет імені І. Я. Горбачевського визначений як базовий для проведення II етапу олімпіади із таких дисциплін, як: анатомія людини, патморфологія, онкологія та ендокринологія. Важливу роль у підготовці студентів до олімпіади відіграють викладачі, відповідальні за проведення олімпіади з навчальних дисциплін, напрямів та спеціальностей, що визначаються завідувачем профільної кафедри. При направленні до участі в II етапі олімпіади враховуються такі характеристики претендентів: відмінне навчання, відсутність усних перескладань іспитів, середній бал успішності, результати ліцензійного іспиту «Крок», участь студента в роботі студентського наукового гуртка. Для забезпечення якісної підготовки студентів до участі в II етапі олімпіади завідувачі профільних кафедр здійснюють підготовку за індивідуальними планами, затвердженими деканами факультетів.

\section{Список літератури}

1. Мороз В. М. Проблеми та перспективи вищої медичної освіти у реалізації Національної стратегії реформування системи охорони здоров’я України / В. М.Мороз, Ю. Й. Гумінський, Л. В. Фоміна // Проблеми та перспективи вищої медичної школи у розробці та реалізації національної стратегії побудови нової системи охорони здоров’я в Україні на період 2015-2025 рр. : тези доп. навч.-метод. конф. - Вінниця, 2015. - С. 3-6.

2. Положення про підготовку та проведення Всеукраїнської студентської олімпіади в ДВНЗ «Тернопільський державний медичний університет імені І. Я. Горбачевського МОЗ України» від 18.09.2015 р. № 409.

3. Положення про проведення Всеукраїнської студентської олімпіади : наказ Міністерства освіти і науки, молоді та спорту України від 13 грудня 2012 р. № 1410 [Елек-

\section{References}

1. Moroz, V.M., Huminskyi, Yu.Y., \& Fomina, L.V. (2015). Problemy ta perspektyvy vyshchoi medychnoi osvity u realizatsii Natsionalnoi stratehii reformuvannia systemy okhorony zdorovia Ukrainy [Problems and prospects of higher medical education in the implementation of the National
У Тернопільському державному медичному університеті імені І. Я. Горбачевського у 2018-2019 навчальному році, за результатами Всеукраїнської студентської олімпіади серед студентів-призерів II етапу Всеукраїнських студентських олімпіад, здобуто 20 призових місць (4 - перших, 5 - других, 11 - третіх), що є важливим показником якості освітньої підготовки майбутніх конкурентоздатних фахівців, а також можливості виявлення та формування кадрового потенціалу вищого медичного закладу.

Висновки та перспективи подальших досліджень. 1. Проведення відбору студентів для участі у Всеукраїнській олімпіаді з клінічних дисциплін повинно бути багатогранним, а не лише до відповідей на теоретичні запитання.

2. Вищенаведена підготовка дозволить краще підготувати студентів для майбутньої олімпіади та виховати фахівця високого рівня кваліфікації.

Розробка заходів комплексного підходу у підготовці студентів до Всеукраїнської олімпіади серед усіх навчальних дисциплін забезпечить кращі результати рейтингу ВНЗ. Проведення предметної олімпіади з хірургії буде сприяти підготовці висококваліфікованих спеціалістів та стане ефективним способом для вдосконалення практичних навичок. Викладачі, аналізуючи знання та навички студентів, підвищать якість викладання дисципліни.

тронний ресурс]. - Режим доступу : https: // zakon.rada. gov.ua/laws/show/z2207-12.

4. Про вищу освіту : Закон від 01.07.2014 p. No 1556-VII [Електронний ресурс]. - Режим доступу : http://zakon3. rada.gov.ua/laws/show/1556-18.

5.Скробач Н. В. Самостійна робота студентів вищих навчальних закладів як важливий елемент сучасної підготовки фахівців / Н. В. Скробач, І. Т. Гаврик, Ю. В. Дельва // Галицький лікарський вісник. - 2014. № 2. - С. 110-111.

6. Шляхи реформування системи вищої медичної освіти в Україні в сучасних умовах / О. В. Лінчевський, В. М. Черненко, Ю. С. П’ятницький, І. Є. Булах // Медична освіта. - 2017. - № 3. - С. 6-9.

Strategy for Health Care System Reform]. Problemy ta perspektyvy vyshchoi medychnoi shkoly u rozrobtsi ta realizatsii natsionalnoi stratehii pobudovy novoi systemy okhorony zdorovia v Ukraini na period 2015-2025 rr.: tezy dop. navch.-metod. konf. - Problems and Prospects of a Higher 
Medical School in the Development and Implementation of a National Strategy for Building a New Health Care System in Ukraine for the Period 2015-2025. Vinnytsia [in Ukrainian].

2. Polozhennia pro pidhotovku ta provedennia Vseukrainskoi studentskoi olimpiady v DVNZ „Ternopilskyi derzhavnyi medychnyi universytet imeni I.Ya. Horbachevskoho MOZ Ukrainy” vid 18.09.2015 r. № 409 [Regulations on the training and holding of the All-Ukrainian Student Olympiad in I. Horbachevsky Ternopil State Medical University Ministry of Health of Ukraine]. [in Ukrainian].

3. Polozhennia pro provedennia Vseukrainskoi studentskoi olimpiady: Nakaz Ministerstva osvity i nauky, molodi ta sportu Ukrainy vid 13 hrudnia 2012 roku №1410 [Regulations on the All-Ukrainian Student Olympiad: Order of the Ministry of Education and Science, Youth and Sports of Ukraine]. Retrieved from: https: // zakon.rada.gov.ua/laws/ show/z2207-12 [in Ukrainian].
4. Pro vyshchu osvitu: Zakon vid 01.07.2014 r. No 1556VII [Law on Higher Education of 01.07.2014 No. 1556-VII]. Retrieved from: http://zakon3.rada.gov.ua/laws/show/155618 [in Ukrainian].

5. Skrobach, N.V., Havryk, I.T., \& Delva, Yu.V. (2014). Samostiina robota studentiv vyshchykh navchalnykh zakladiv yak vazhlyvyi element suchasnoi pidhotovky fakhivtsiv [Independent work of students of higher educational institutions as an important element of modern training of specialists]. Halytskyi likarskyi visnyk-Galician Medicinal Herald, 2, 110-111 [in Ukrainian].

6. Linchevskyi, O.V., Chernenko, V.M., Piatnytskyi, Yu.S., \& Bulakh, I.Ye. (2017). Shliakhy reformuvannia systemy vyshchoi medychnoi osvity v Ukraini v suchasnykh umovakh [Ways of reforming the system of higher medical education in Ukraine in modern conditions]. Medychna osvita - Medical Education, 3, 6-9 [in Ukrainian].

Електронна адреса для листування: andrew_burak@tdmu.edu.ua 